\title{
Lumen
}

Selected Proceedings from the Canadian Society for Eighteenth-Century Studies

\section{Vauvenargues' Quest for a New Moral Philosophy}

\section{Paul Meagher}

Volume 13, 1994

URI : https://id.erudit.org/iderudit/1012528ar

DOI : https://doi.org/10.7202/1012528ar

Aller au sommaire du numéro

Éditeur(s)

Canadian Society for Eighteenth-Century Studies / Société canadienne d'étude du dix-huitième siècle

ISSN

1209-3696 (imprimé)

1927-8284 (numérique)

Découvrir la revue

Citer cet article

Meagher, P. (1994). Vauvenargues' Quest for a New Moral Philosophy. Lumen, 13, 125-136. https://doi.org/10.7202/1012528ar d'utilisation que vous pouvez consulter en ligne.

https://apropos.erudit.org/fr/usagers/politique-dutilisation/ 


\section{Vauvenargues' Quest for a New Moral Philosophy}

L'homme est maintenant en disgrâce chez tous ceux qui pensent et c'est à qui le chargera de plus de vices; mais peut-être est-il sur le point de se relever et de faire restituer toutes ses vertus. ${ }^{1}$

Luc de Clapiers, marquis de Vauvenargues, sensed a growing revolt against a gloomy debilitating view of man that was all too prevalent, the result of the pernicious influence of the Pyrrhonists and of the major moralists of the French Classical Age, in particular La Rochefoucauld and Pascal. Reason was seen as the slave of the passions, powerless to lead man to truth and virtue. Man, it seemed, was as prone to vice as he was incapable of virtue.

The aim of this study is to demonstrate that Vauvenargues' ethical reflections, despite inconsistencies and contradictions, reveal an underlying unity - a rejection of the pessimistic view of man of the preceding age and an optimistic affirmation of man's moral worth. ${ }^{2}$

Vauvenargues believed that the disparagement by the skeptics ${ }^{3}$ of man's rational faculties combined with the vilification of the instinctive side of man had resulted in a distorted view of human nature which rendered men disheartened and morally paralysed: 'Il faut qu'ils se connaissent capables de vertu,' he wrote, 'afin qu'ils ne se désespèrent pas d'eux-mêmes.'4 Above all he sought certainty and he was determined to restore man's faith in the reality of virtue and his capacity to achieve it. Moreover he was convinced that a sound moral philosophy could rest secure only when he had undermined the arguments of the pessimists and skeptics.

Pyrrhonism was not only a false doctrine but a destructive philosophy which led to moral decay. He attacked those who 'nous présentant toutes choses comme incertaines... anéantissant le mérite de la vertu et, n'admettant parmi des hommes que des apparences, égalent le bien et le mal. ${ }^{5}$ To those who denied the existence of virtue, he used the argument of common sense: 
Une vérité s'offre à moi, ceux qui nient la réalité des vertus sont forcés d'admettre des vices. Oseraient-ils dire que l'homme n'est pas corrompu et méchant? Toutefois, s'il n'y avait que des malades, saurions-nous ce que c'est que la santé? ${ }^{6}$

However faulty his logic might be, he was convinced that virtue was not a 'fantôme' but that it existed and that 'rien ne peut l'effacer."

He singled out for special criticism La Rochefoucauld's work 'qui détourne encore aujourd'hui des hommes de la vertu en leur persuadant qu'il n'y a point de véritable. ${ }^{8}$ Vauvenargues never tired of extolling man's capacity for virtue: 'Pourquoi veulent-ils nous détourner de la vertu en insinuant que nous en sommes incapables, et moi, je leur dis que nous en sommes capables. ${ }^{9}$

Permeated or at least tinged with the Jansenistic outlook, the pessimists of the Classical Age had insisted on the moral corruption of human nature which seemed not a mere hypothesis but a reality borne out by the facts of experience.

Convincing evidence of man's depravity was found in the concept of inherent 'amour-propre' which included both egoistic calculation and the subversive force of the passions. It was an all pervasive selfish love that was the unique motive of all man's actions and the inevitable source of evil. For La Rochefoucauld, even acts which appeared altruistic or disinterested, even acts whose results were useful to society, were in the last analysis wicked since they were based on egoistic motives. What passed for virtue was only disguised vice.

Convinced that the moral worth of an action depended, at least in part, upon the motivation, Vauvenargues set out to demonstrate that man was not despotically governed by an all pervading selfishness. He made a crucial distinction between a selfish and unjust 'amour-propre' and a blameless 'amour de soi' which by a natural expansion of outlook and interests led men to participate in the social well-being of the community, 'un amour de nous-mêmes naturellement officieux et compatissant. ${ }^{10}$ Man, he asserted, was essentially a moral being with natural altruistic impulses, capable of generosity and even disinterested acts. Compassion was a spontaneous disinterested feeling for the suffering of others and benevolence was just as natural: 'La magnanimité ne doit pas compte à la prudence de ses motifs. ${ }^{11}$ The manifest preference for someone or something beyond the self, illustrated by love, the sacrifice of one's life for another or for one's country clearly indicated that there were more noble mainsprings for our action than selfishness.

Vauvenargues freely admitted the imperfections and weakness of human nature but there was no reason to lose heart: 'Consolons-nous de nos défauts puisqu'ils nous laissent toutes nos vertus. ${ }^{12}$ Above all he rehabilitated the non-rational elements of man's nature which had been 
so long assailed by pessimists and rationalists alike. Human nature was not vitiated by original sin and the passions, far from being depraved and a source of evil, were our motive force, the source of all human vitality and creative activity. Moreover, there was no conflict between the spirit and the flesh. Reason and sentiment worked together in harmony and both were noble sources of virtue. ${ }^{13}$ He refuted the views of the pessimists who denied spontaneous virtue, who insisted that virtue implied the repudiation of one's natural impulses, who claimed that no conduct was virtuous unless the motivation was rational. ${ }^{14} \mathrm{He}$ also rejected the views of those who argued that a praiseworthy action which was not instinctive was somehow inferior:

Quand il serait vrai que les hommes ne seraient vertueux que par raison, que s'ensuivrait-il? Pourquoi, si on nous loue avec justice de nos sentiments, ne nous louerait-on pas encore de notre raison. ${ }^{15}$

Vauvenargues shared the common assumptions of the age; namely, the belief in the uniformity of human nature and the belief in a natural law that was universal, eternal and invariable. Such a law was engraved within our hearts and all men had, at least, a rudimentary intuitive sense of what was right and wrong: 'Il y a des semences de bonté et de justice dans le cœur des hommes. ${ }^{16}$ Not only were man's feelings and natural impulses essentially good but justice was natural to man and preceded any man-made laws. Generally speaking, vice was unnatural to man: 'Son inclination et sa raison y répugnent trop fortement. ${ }^{17}$ There is little doubt that he proposed an optimistic view of unaided human nature and man's potential for virtue: 'Nous sommes susceptibles d'amitié, de justice, d'humanité, de compassion, et de raison. O mes amis, qu'est-ce donc que la vertu? ${ }^{18}$ He refused to judge man only by his outward behaviour since a man's actions were often a misleading expression of his real intentions and might lead to undeserved blame. Such actions were often the result of chance or accident or dictated by factors beyond his control: 'Il ne faut pas mesurer les hommes par leurs actions, qui sont trop dépendantes de leur fortune, mais par leurs sentiments et leur génie. ${ }^{19}$ If unable to commend the act itself, he sought to praise the nobility of intention or, at least, to excuse man for his shortcomings.

It is not surprising that, with such an outlook, he spurned the austere Christian morality of the Augustinian tradition and of Jansenism for whom virtue necessitated self-denial. The emphasis on man's sinfulness and unworthiness was in stark opposition to his central theme, which was man's essential goodness, and could only lead to discouragement, for it betrayed man's energy and life force and implied a deep-rooted pessimism regarding human nature. He denounced those 'qui combat- 
tent par la religion ce qu'il y a de meilleur dans la nature. ${ }^{, 20} \mathrm{~A}$ rigid puritanical concept of morality, which advocated repression of one's natural instincts, was a denial of life itself. The repressive aspects of such an ethical system were responsible for much of man's unhappiness:

C'est elle qui empoisonne leurs plaisirs, qui trouble leur félicité présente, qui leur donne des regrets sur le passé, et des craintes sur l'avenir. C'est elle, enfin, qui tyrannise leurs passions, et qui veut leur interdire les deux sources d'où la nature fait couler nos biens et nos maux, l'amour-propre et la volupté, c'est-à-dire tous les plaisirs des sens, et toutes les joies du cœur. ${ }^{21}$

Insofar as he saw Christianity as the enemy of pride, self-confidence and sensuality, he opposed it.

A religion of regrets, fear, and guilt which destroyed man's natural pleasures and legitimate love of self was repugnant to him. His hatred of severity and repression was a recurring theme: 'La morale austère anéantit la vigueur de l'esprit pour détruire un vice souvent imaginaire. ${ }^{, 22} \mathrm{He}$ furthermore objected to the otherworldliness of Christianity, for the goal of life was maximum self-realization here on earth: 'La pensée de la mort nous trompe, car elle nous fait oublier de vivre. ${ }^{23}$ Indeed, 'il faut vivre, comme si on ne devait jamais mourir. ${ }^{24}$ It is true that he realized the usefulness of religion as a means of social control. For the selfish few it was an effective policeman, able to buttress the state's system of punishments and rewards. ${ }^{25}$ Nevertheless, for Vauvenargues, there was no need of religious belief in order to lead a virtuous life and he endeavoured to separate ethics from theology and to set morality on its own feet.

But what exactly was this virtue of which man was capable? As interest shifted from the individual to the group, as was more and more the case in the eighteenth century, the result of an action for society became more important than the motivation. To act virtuously was to act in a way beneficial to society. Social utility was more and more considered the criterion of virtue. Vauvenargues, in fact, made one of the first clear statements in France of the utilitarian ethic. In a section entitled 'Du Bien et du Mal Moral,' which Voltaire greatly admired, he defined virtue as follows:

Le mot de vertu emporte l'idée de quelque chose d'estimable à l'égard de toute la terre; le vice au contraire.... La préférence de l'intérêt général au personnel est la seule définition qui soit digne de la vertu et qui doive en fixer l'idée; au contraire, le sacrifice mercenaire du bonheur public à l'intérêt propre est le sceau éternel du vice. $^{26}$ 
Just as he was convinced that by imputing to man noble motives he could defend him against moral censure, so too was he certain that by using utilitarian arguments, by setting forth such a clear objective distinction between virtue and vice, he could confound the skeptics who denied their reality:

Que prétendent donc quelques hommes, qui confondent toutes ces choses, ou qui nient leur réalité? Qui peut les empêcher de voir qu'il y a des qualités qui tendent naturellement au bien du monde, et d'autres à sa destruction? Ces premiers sentiments... bienfaisants à tout l'univers, et par conséquent estimables à l'égard de toute la terre, voilà ce qu'on nomme vertu. ${ }^{27}$

Man was by nature a social being ${ }^{28}$ and had a natural feeling for these distinctions.

With glee he dismissed the objections of the gloomy moralists who insisted that virtue was incompatible with pleasure or happiness. After defining virtue as 'un sacrifice de notre intérêt-propre à l'intérêt public' he continued:

Peut-être ne faisons-nous le bien que parce que notre plaisir se trouve dans ce sacrifice. Etrange objection! Parce que je me plais dans l'usage de ma vertu, en est-elle moins profitable, moins précieuse à tout l'univers ou moins différente du vice, qui est la ruine du genre humain?... Qu'ils sachent qu'un Dieu bon et juste ne peut réprouver le plaisir que lui-même attache à bien faire. Nous prohiberait-il ce charme qui accompagne l'amour du bien? Lui-même nous ordonne d'aimer la vertu et sait mieux que nous qu'il est contradictoire d'aimer une chose sans $s^{\prime} y$ plaire. ${ }^{29}$

Self-interest and social interest were not irreconcilable. By calculated reflection, by enlightened 'amour-propre,' men would realize that they were acting in their own interest when they acted for the common good. The utility of virtue was so obvious that 'les méchants la pratiquent par intérêt. ${ }^{30}$ He refused, moreover, to condemn 'amour-propre' if it had no harmful effects on society. ${ }^{31}$ If not carried to excess, amour-propre was both natural and legitimate.

Like the Jansenists and Mandeville, ${ }^{32}$ he emphasized the usefulness of passions such as greed, vanity, ambition and avarice which maintained commerce and industry and frequently benefited mankind. Actions performed under the influence of purely selfish affection or through unworthy motives were still in some sense virtuous if advantageous to mankind and he concluded: 'Que sera-ce si ces prétendus vices, qui soutiennent les empires et les font fleurir, sont de véritables vertus?' ${ }^{33}$ Although good produced by vice was mixed with evil, private 'vices' 
could serve the common good and hence become public virtues. Whatever the motives might be, the consequences were excellent. He reassessed the inherited ideas on vice and virtue. A vice, if it led to a worthy end, was no longer a vice.

Was Vauvenargues convinced that no act had any intrinsic value, its value depending solely on whether it benefited or harmed society? Was there no single ethical criterion for judging a man's worth? He implied that the moral worth of an action depended not only on its motivation but also on its consequences for society. He was, however, not content to prove that egoistic motives were not at the root of all man's actions or even that man was essentially a moral being capable of generosity and disinterested acts. Nor was he completely satisfied with the social benefits of individual actions as a sign of inner moral worth. At times, a purely social morality was only grudgingly recognized as a necessary, though uninspiring, criterion for virtue. ${ }^{34}$ Despite his concern for social utility he did not believe that the good was merely synonymous with the useful.

Vauvenargues had yet another concept of virtue, a deeply felt, personal, and highly individualistic one, only incidentally fused with social morality and which he defined as 'la supériorité des âmes fortes et tendres sur les âmes faibles. ${ }^{35}$ It was a doctrine of invigorating encouragement, a belief in man's ability to be great in misfortune, superior in defeat, heroic in need. Great emphasis was placed on virtue as a state of character rather than on any extrinsic end to be achieved by an act: 'Le mérite et le courage triomphent de tout. ${ }^{36}$ By inner fortitude man could overcome all obstacles and become master of his destiny. In the struggle against misfortune there was nobility: 'Je remercie à genoux la nature de ce qu'elle a fait des vertus indépendantes du bonheur et des lumières que l'adversité n'a pas pu éteindre. ${ }^{37}$ In his preoccupation with establishing a new value system, he stressed the concept of personal superiority. He made a qualitative distinction between the independent strong men of passion, of creative energy and action and the majority of weak, mediocre and dependent men who merely conformed to society's norms. Such superiority which consisted of 'la bonté et la vigueur de l'âme' had two characteristics which were not mutually exclusive. First was the Roman virtus, a heroism he learned as an adolescent in his readings of Plutarch and Seneca with their emphasis on limitless activity and heroic courage. To this he added kindness and benevolence. His ideal was the great-hearted Prometheus who combined boundless compassion with limitless energy and self-assertion. It was an ethic involving intense feeling and strong passions, an ethic in which ambition and the search for glory were essential ingredients and the source of all greatness. Such virtue was based on the idea of self-perfection, unconcerned with public constraints, far removed from the monkish virtues of self-denial 
and humility, and beyond the criterion of social benefit. It consisted not only of 'cette force et cette grandeur de l'âme ${ }^{38}$ but also of humanitas 'la première des vertus ${ }^{39}$ the supreme virtue uniting all men in brotherhood. Only the spirit of humanity was in keeping with a true understanding of men and 'leurs malheurs toujours plus grands que leurs vices. ${ }^{40}$ Vice was a misfortune in his eyes. It was not his innate wickedness but rather his weakness, unfortunate circumstances, or poverty which led him to vice. It was not man's vicious nature but largely bad education, bad customs and bad laws which all too often thwarted or depraved man.

Vauvenargues deplored the moral degradation of his age where weak mediocre vices seemed to dominate: frivolity, pettiness, vanity and sloth. Such vices he did not consider inherent in human nature or inevitable but rather artificial accretions that could be corrected through proper education in accord with his nature. He felt as well that the moral superiority of great men in his age, as in all ages, more than compensated for the limitations of others and could serve as a model for all to imitate.

He was dedicated to a higher moral ideal based on the natural superiority of an elite. Despite his regret that greatness and virtue were not always found together, he insisted that 'il y a des vices qui n'excluent pas les grandes qualités, et par conséquent, de grandes qualités qui s'éloignent de la vertu' ${ }^{41}$ There was a greatness, then, beyond good and evil. Admirable qualities could be found even in great criminals and he admired Cataline for his courage and force of character despite his heinous crimes. This refusal to condemn and the will to commend man were carried to great lengths by Vauvenargues, almost to the point of an apology for crime:

L'homme infâme attache mes yeux sur la sorte de courage qui soutient son infâmie, le crime et l'audace me montrent des âmes au-dessus de la crainte, au-dessus des préjugés, libres dans leurs pensées, fermes dans leurs desseins. ${ }^{42}$

What then are we to make of Vauvenargues' confused moral philosophy? There is no doubt that Vauvenargues' ethical speculation resulted in certain inconsistencies and contradictions. Was virtue an action whose merit depended on its non-egoistic motivation or was the motive of no concern, the result of an action being the sole criterion for judging its moral worth? Was virtue only that which benefited society, a social morality, or was it a combination of heroic courage, and 'bienfaisance,' something intrinsically worthy of admiration? How much weight are we to attach to these various factors? His premature death, the bewildering variety of theme and literary forms that he employed and the fact that his philosophy was strongly coloured by subjective emotional elements ${ }^{43}$ 
led to a great discrepancy between the results and his stated intention to explain the principles of morality. His chief aim was not the intellectual consistency of a systematic disinterested philosopher but rather the search for self-assurance and certainty. His unshakeable faith in man's moral excellence was as much a profound need of the heart as it was an intellectual conviction, a bulwark against the temptation to despair.

Yves Lainey has written of Vauvenargues' 'doctrine nullement optimiste... empreinte d'un pessimisme moral et spirituel courageusement supporté mais foncier et... irrémédiable. ${ }^{44}$ On the contrary, Vauvenargues' ethical reflections reveal a persistent optimism. They reveal not so much the vacillations of a young uncertain mind but rather the unwavering determination to excuse and ennoble man. His refutation of Pyrrhonism and pessimism, his insistence on non-egoistic motivation while at the same time promoting utilitarian views, as well as his own personal moral philosophy combining heroic courage and compassion, can only be understood in the light of this singleness of purpose to defend man.

Did Vauvenargues fail in his quest for a new moral philosophy? He was above all an eclectic, pragmatic thinker. One is struck, however, less by the contradictions and inconsistencies than by the underlying unity, the resolve to defend man against all his detractors, to repudiate the doctrine of man's intellectual impotence and moral decadence. There was, indeed, a singleness of purpose in all that he wrote, to restore man to his true position of dignity and nobility, to demonstrate that man by nature was capable of moral greatness.

Such lofty moral idealism is no less relevant to our age with its pervasive skepticism, cynicism and extreme relativism, an age which has seen the rejection of any fixed moral creed and seems to have lost confidence in man himself.

PAUL MEAGHER

Royal Military College

\section{Notes}

The following abbreviations are used:

G.I CEuvres de Vauvenargues, ed. D.L. Gilbert (Paris, 1857).

G.II CEuvres posthumes et 'uvres inédites de Vauvenargues, ed.

D.L. Gilbert (Paris, 1857).

1 G.I, p. 400. Despite Vauvenargues' exaggeration of the pessimism of his age, he knew that a virtual revolution in man's attitude to man was under way. He was certainly not alone in his attempts to restore faith in man. Indeed, the rejection of a gloomy vision of the human condition and the elaboration of a more cheerful view of man were perhaps most cogently expressed in the early works of his 
friend and mentor, Voltaire, whose writings he knew so well. L. Crocker asserted that 'by and large, pessimism about man, both theological and secular, was dominant' in the Age of Enlightenment. See L.G. Crocker, An Age of Crisis; Man and World in Eighteenth Century French Thought (Baltimore, 1959) p. XIII. However, R. Mercier's La Réhabilitation de la nature humaine, 1700-1750 (Villemomble, 1960) and J. Ehrard's L'Idée de nature en France dans la première moitié du XVIII siècle (Paris, 1963) have demonstrated that optimism concerning human nature was the dominant note in the first fifty years of the century, and this was the age of Vauvenargues.

2 There has been no agreement as to what constituted the essential unity, if any, of his thought. Indeed most scholars have insisted on the lack of unity in his writings. See M. Wallas, Luc de Clapiers, Marquis de Vauvenargues (Cambridge: Cambridge University Press, 1928); G. Lanson, Le Marquis de Vauvenargues (Paris, 1932). A few others, however, have seen a fundamental unity in his works. See E. Bréhier, Histoire de la philosophie (Paris, 1930), 11, ch. IX, p. 431; M. Pelisson 'La Rénovation des idées morales au XVIII ${ }^{\mathrm{e}}$ siècle,' Grande Revue, 16 November 1904, p. 350, and F. Vial, Une Philosophie et une morale du sentiment, Luc de Clapiers, marquis de Vauvenargues (Geneva, 1938), p. 284. Most critics have contradicted one another in their diverse and conflicting views of his thought. Many have seen him as a pessimistic moralist. See Henry Vyverberg, Historical Pessimism in the French Enlightenment (Cambridge, Massachusetts, 1958), p. 104; A. Maurois, 'Vauvenargues' in his Tableau de la littérature française: dix-septième et dix-huitième siècles (Paris, 1939), pp. 363-7 and L.G. Crocker, Nature and Culture: Ethical Thought in the French Enlightenment (Baltimore, 1963), p. 283. Others have stressed his optimism. See S. Rocheblave, Vauvenargues ou la symphonie inachevée (Paris, 1934), p. 61 and G. Michaut, Vauvenargues, Réflexions et Maximes (Paris, 1937) p. 96.

3 Vauvenargues wrote: 'Quel abîme! ... Qui sait ce qu'il doit estimer ou mépriser ou haïr, s'il ne sait pas ce qui est bien ou ce qui est mal' (G.I, p. 2). Vauvenargues' enemy is, above all, Pierre Bayle, the most influential skeptic of the age. His influence was enormous especially from about 1715 to 1750 . For Vauvenargues' criticism of Bayle, see G.II, p. 246. Vauvenargues insisted that skepticism 'a fait des progrès rapides: ce n'était d'abord que le ton d'un petit nombre de beaux esprits; aujourd'hui c'est une des modes du peuple' (G.I, p. 100). He ridiculed and deplored the attitude of the skeptical 'bel esprit': 'Il a vu le fort et le faible de tous les principes, et il a reconnu que l'esprit n'avait que le choix de ses erreurs. Indulgente philosophie, qui égale Achille et Thersite, et nous laisse la liberté d'être ignorants, paresseux, frivoles sans nous faire de pire condition' (G.I, p. 100). He was also critical of the eroding skepticism of Montaigne and Fontenelle. See G.I, p. 275, and G.I, pp. 356-57. He was very much a part of his age in his rejection of skepticism. R.H. Popkin has spoken of the Enlightenment's commitment to utilitarian optimism and its refusal to recognize the serious challenge of Pyrrhonism. See R.H. Popkin 'Scepticism in the Enlightenment,' Studies on Voltaire and the Eighteenth Century, XXVI (1963), 1321-45.

4 G.I, p. 164. His most serious objection to such pessimism was his belief in its morally dangerous effects. To deprecate human nature and destroy our confidence and self-esteem had disastrous consequences and sapped man's energy. See also G.I, max. 285, pp. 414-15, and G.I, p. 164.

5 G.I, p. 169. He insisted that 'la corruption des principes est cause de celle des mœurs' (G.I, p. 164).

6 G.I, p. 56. 
7 G.I, p. 54.

8 G.II, p. 75. For a detailed study of Vauvenargues and his 'bête noire,' La Rochefoucauld, see Peter Martin Fine, Vauvenargues and La Rochefoucauld (Manchester: Manchester University Press, 1974). Pascal's gloomy vision of the human condition was no less abhorrent to Vauvenargues but he knew that Voltaire had already made a penetrating rebuttal of Pascal in the Lettres Philosophiques. See H. Mydlarski's article 'Vauvenargues, lecteur de Pascal,' Revue des Sciences Humaines (avril-juin, 1972), pp. 210-23.

9 G.I, p. 162

10 G.I, max. 291, p. 416. Jacques Abbadie was the first to make a sharp and clear distinction between the two terms. See J. Abbadie, L'Art de se connaitre soi-même (Rotterdam, 1692), p. 265.

11 G.I, max. 130, p. 386. Voltaire remarked: 'C'est grand.' See also G.I, pp. 29-30. Voltaire carefully annotated a copy of the first edition of Vauvenargues' works in 1746 , covering the margins with notes of approval, suggestions and criticism. The key document is to be found in the Bibliothèque Méjanes in Aix-en-Provence and it has aroused considerable controversy. See Jeroom Vercruysse, 'Vauvenargues trahi: pour une édition authentique de ses 'uvres,' Studies on Voltaire and the Eighteenth Century, CLXX, 1977.

12 G.I, pp. 126-7. With Pascal in mind he wrote: 'Nous avons grand tort de penser que quelque défaut que ce soit puisse exclure toute vertu, ou de regarder l'alliance du bien et du mal comme un monstre ou comme une énigme' (G.I, max. 287, p. 415)

13 'J'appelle vertus naturelles les vertus de tempérament; les autres sont les fruits pénibles de la réflexion' (G.I, p. 427). He also stated: 'La raison et le sentiment se conseillent et se suppléent tour à tour' (G.I, max. 150, p. 339). For his praise of reason, see G.I, max. 202, p. 395, G.I, p. 94 and G.II, p. 25.

14 The enemy is La Rochefoucauld who denied that virtue was ever natural or spontaneous. Vauvenargues parried point by point the cynical indictment of mankind found in that work. See G.II, pp. 77-78. Nowhere, in fact, did the idealistic Vauvenargues see eye to eye with the author of the Maximes. For example, he found in compassion a positive sentiment which reinforced his optimistic view of human nature: 'La pitié n'est qu'un sentiment mêlé de tristesse et d'amour; je ne pense pas qu'elle ait besoin d'être excitée par un retour sur nous-mêmes, comme on le croit. Pourquoi la misère ne pourrait-elle sur notre cœur ce que fait la vue d'une plaie sur nos sens?' and he concludes: 'Notre âme est-elle incapable d'un sentiment désintéressé?' G.I, p. 43. He described the error of an adversary whom he refers to as 'l'esprit présomptueux' as follows: 'Il ose assurer que la vertu n'est qu' un fantôme... Si on lui nomme M. de Turenne ou le maréchal de Vauban, si sincèrement vertueux malgré la mode, il n'estime pas de tels personnages, qui n'ont été grands, dit-il, que par instinct... En un mot, il est convaincu qu'on ne fait de véritablement grandes choses que par réflexion, et rapporte tout à l'esprit, comme tous ceux qui manquent par le cœur' (G.I, pp. $307-08)$. Vauvenargues consistently praised the instinctive side of man.

15 G.I, max. 292, p. 416.

16 G.I, p. 410. Like Voltaire, he believed that there was a morality common to all men. There existed a consensus on what constituted the basic characteristics of virtue, which were the same everywhere. The natural law had the added 
advantage of providing a sure basis for a critique of existing laws and institutions. See Henry Vyverberg, Human Nature, Cultural Diversity and the French Enlightenment (Oxford: Oxford University Press, 1989) for an illuminating discussion of natural law.

17 G.I, note 5, var. p. 416.

18 G.I, max. 298, p. 417. Vauvenargues asked rhetorically: 'L'homme capable de raison, serait-il incapable de vertu?'

19 G.I, p. 106.

20 G.I, p. 132.

21 G.II, p. 146.

22 G.I, max. 546, p. 451. Vauvenargues wrote often of 'des vertus et des vices imaginaires' (G.I, max. 122, p. 385).

23 G.I, max. 143, p. 388.

24 G.I, p. 142.

25 He saw in religion a powerful force 'pour donner un frein à la cupidité des hommes' (G.I, p. 51). See also G.I, p. 223 and G.I, max. 563, p. 453.

26 G.I, p. 52.

27 G.I, p. 54 .

28 The doctrine of Hobbes that man was unsocial and the enemy of his fellow man found little acceptance in France among the 'philosophes'. Ehrard has commented as follows on this opposition to Hobbes in the first half of the eighteenth century: 'L'homme est naturellement sociable. Contre la désolante philosophie de Hobbes, le demi-siècle tout entier ne se lasse pas de le proclamer' (Ehrard, op. cit., 11, p. 471).

29 G.I, p. 56. Voltaire noted, 'Admirable!' Vauvenargues, curiously enough, had little to say about happiness, a concept which so obsessed his contemporaries.

30 G.I, max. 759, p. 477.

31 He wrote: 'Si l'intérêt-propre y domine, j'ose dire que cela est non seulement selon la nature, mais aussi selon la justice pourvu que personne ne souffre de cet amour-propre ou que la société y perde moins qu'elle n'y gagne' (G.I, max. 294, p. 416).

32 Even though the Jansenist Nicole condemned 'amour-propre' as intrinsically evil and totally corruptive of man's motivation, he believed also in an 'amour-propre éclairé' which could bring about peace, order, and happiness in society. See P. Nicole, Essais de morale, 'De la charité et de l'amour-propre,' 3rd ed., 111 (Paris, 1675), pp. 205-06. For Mandeville as well, man's nature was fundamentally corrupt. Man, irrational and completely selfish, was incapable of true virtue. Although Mandeville's psychology was pessimistic, he developed the paradox, similar to that of Nicole, that private vices were, in fact, public benefits. His conclusion was optimistic: 'Thus every part was full of vice, yet the whole mass a Paradise,' B. Mandeville, The Fable of the Bees, ed. F.B. Kaye (Oxford, 1924), 1, 18.

33 G.I, p. 168.

34 See G.II, pp. 187-8.

35 G.I, note 1, var. p. 417. 
36 G.I, p. 115.

37 G.I, p. 84.

38 G.I, p. 162.

39 G.I, max. 441, p. 442.

40 G.I, p. 435.

41 G.I, p. 58. He admired the moral grandeur of Greek and Roman heroes and stated: 'La liberté découvre, jusque dans l'excès du crime, la vraie grandeur de notre âme,' and 'les vices sans bassesse' (G.II, pp. 192-93). The existence of 'la grandeur d'âme' was self-evident, 'quelque chose d'aussi réel que la santé' (G.I, p. 56). He also took exception to La Rochefoucauld's apparent pleasure in denigrating heroism: 'Il est donc faux de dire que c'est une grande vanité qui fait les héros, puisque c'est, au contraire, le mépris des choses vaines qui les rend supérieurs aux autres hommes' (G.II, p. 78).

42 G.I, p. 60. He objected to conventional morality where individuals were often blamed for their strengths and praised for their weaknesses. He proposed an ethic of moral strength and self-realization. He certainly hinted at a new morality of amoral dynamism which presages Nietzsche's later philosophy.

43 A strange philosopher, indeed, who wrote: 'Toute ma philosophie a sa source dans mon cœur' (G.II, p. 115). See also G.II, p. 165. If he failed to construct a completely coherent moral philosophy, this was perhaps owing to the important role played by the emotions in his life and works. These fluctuating emotions explain, at least in part, certain inconsistencies in his thought, inconsistencies which he readily admitted: 'Si quelqu'un trouve que je me contredis, je réponds: parce que je me suis trompé une fois ou plusieurs fois, je ne prétends point me tromper toujours' (G.I, max. 643, p. 462).

44 Yves Lainey, Les Valeurs morales dans les écrits de Vauvenargues, Essai (Paris, 1975), p. 99. Did Vauvenargues not give us a clue to his thinking when he stated: 'Pour décider qu' un auteur se contredit, il faut qu'il soit impossible de le concilier' (G.I, max. 945, p. 493). 